\title{
SCAPHYGLOTTIS COBANENSIS (ORCHIDACEAE, EPIDENDROIDEAE), A NEW SPECIES FROM GUATEMALA
}

\author{
Fredy Archila Morales, Dariusz L. Szlachetko \& SŁawomir Nowak ${ }^{1}$
}

\begin{abstract}
Scaphyglottis cobanensis Archila, Szlach. \& S. Nowak (Orchidaceae, Epidendroideae) is described and compared with the morphologically close species $S$. bifida (Rchb. f.) C. Schweinf. and S. lindeniana (A. Rich. \& Galeotti) L. O. Williams. The new species is illustrated with SEM images of the labellum and gynostemium.
\end{abstract}

Key words: epiphyte, Guatemala, new species, Scaphyglottis, taxonomy

Fredy Archila Morales, Estación Experimental de orquídeas de Guatemala; Herbario BIGU, Universidad de San Carlos de Guatemala, Zona 12, Guatemala City, Guatemala

Dariusz L. Szlachetko \& Stawomir Nowak, Department of Plant Taxonomy and Nature Conservation, University of Gdańsk, Wita Stwosza 59, 80-308 Gdańsk, Poland; e-mail: slawomir.nowak@ug.edu.pl

\section{INTRODUCTION}

The genus Scaphyglottis Poepp. \& Endl. (Orchidaceae, Epidendroideae) includes $c a 75$ accepted species; several new species were proposed recently (Dressler 2002, 2004; Archilla 2012; Archilla \& Chiron 2013; Kolanowska 2013; Szlachetko \& Kolanowska 2013a, b, 2014). Representatives of Scaphyglottis are distributed from Mexico to Brazil and Bolivia; the diversity center of the genus is Costa Rica and Panama. Most species grow epiphytically, but semiterrestrial species on broken branches and even lithophytes are sometimes recorded. The most common habitats of Scaphyglottis species are humid and wet forest as well as cloud forest (Dressler 2005; Szlachetko \& Kolanowska 2013a).

Morphologically, Scaphyglottis species are characterized by the presence of pseudobulbs arising from the rhizome or the apical part of older pseudobulbs, resupinate or nonresupinate flowers with free, similar sepals, usually wider than the petals, and commonly a prominent column-foot. High diversity of leaf blade and internode shape, the form of the lip and its fusion with the gynostemium, and number of pollinia,

\footnotetext{
1 Corresponding author
}

have resulted in the division of Scaphyglottis into smaller, morphologically more coherent genera: Costaricaea Schltr., Hexisea Lindl., Platyglottis L. O. Williams, Reichenbachanthus Barb. Rodr. and Tetragamestus Rchb. f. However, molecular studies of Scaphyglottis (Dressler et al. 2004) support the earlier proposal to conserve the genus sensu lato (Dressler 1994).

Recent studies of Scaphyglottis by the senior author in Guatemala revealed a peculiar species which we describe here as new. Including the newly proposed entity, 17 species have been recorded in Guatemala so far.

\section{TAXONOMIC TREATMENT}

Scaphyglottis cobanensis Archila, Szlach. \& S. Nowak, sp. nov.

Figs $1 \& 2$

Scaphyglottis cobanensis is similar to S. bifida (Rchb. f.) C. Schweinf. and S. lindeniana (A. Rich. \& Galeotti) L. O. Williams but is easily distinguished by its rose to dull brownish flowers, the lip truncate at the base, and large, ligulate, acute leaves.

Holotype: GUATEMALA. Cobán, San Pedrito, alt. 1450 m, Sep. 2014, F. Archila s.n. (BIGU; ISOTYPE: USCG). 


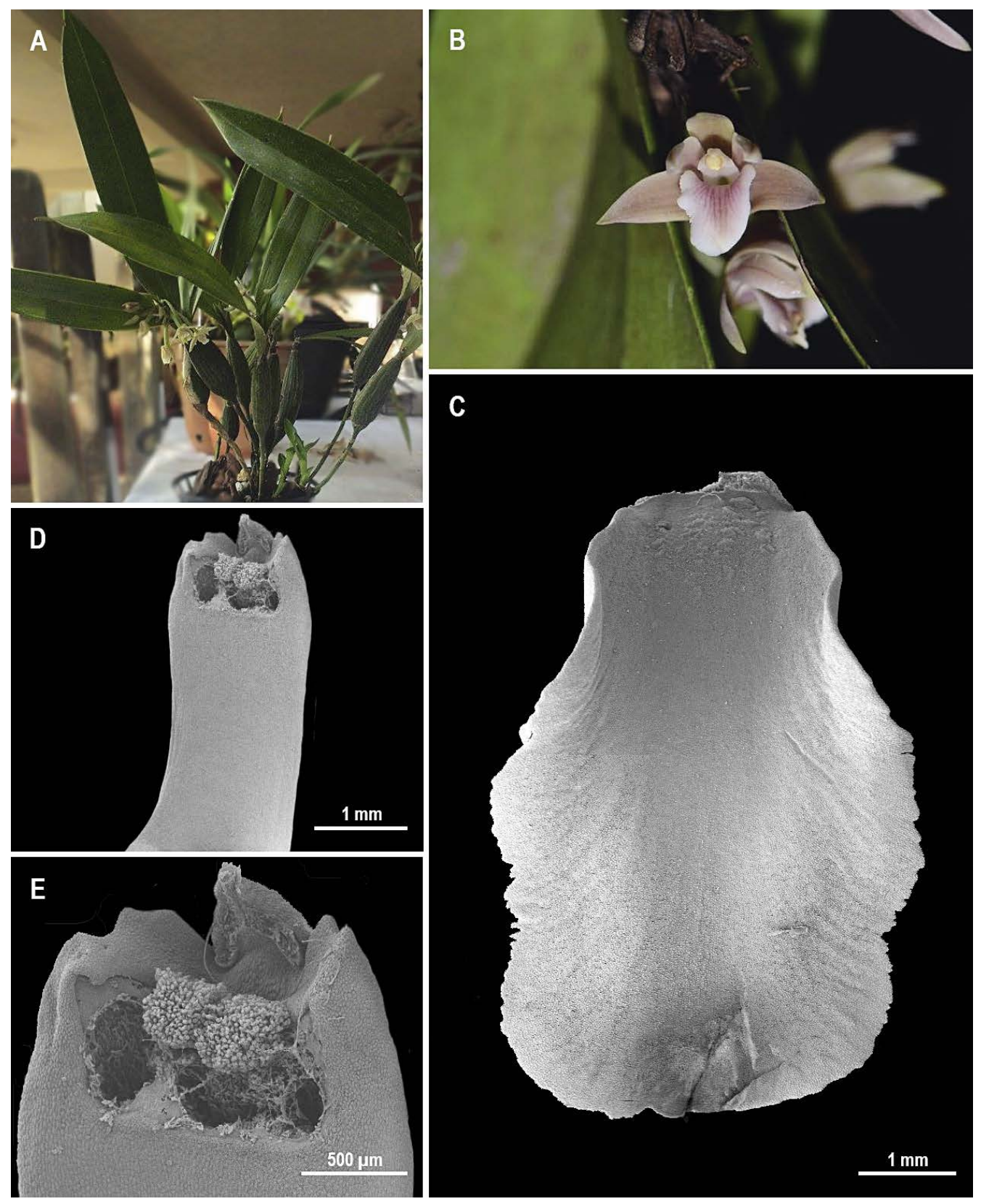

Fig. 1. Scaphyglottis cobanensis Archila, Szlach. \& S. Nowak, sp. nov. A - plant, B - flower, C - labellum, D - column, E - apical part of column.

Plant epiphytic, up to $15 \mathrm{~cm}$ tall; roots ca $0.09 \mathrm{~cm}$ in diameter, numerous, flexuous, simple; pseudobulbs ca $12 \mathrm{~cm}$ long and $2.5 \mathrm{~cm}$ in diameter, abruptly stalked, oblong-ellipsoid, lat- erally compressed, bifoliate; leaves up to $12 \mathrm{~cm}$ long and $3 \mathrm{~cm}$ wide, ligulate, attenuate towards base and acute apex. Flowers open a few at a time, produced along elongate inflorescence, 

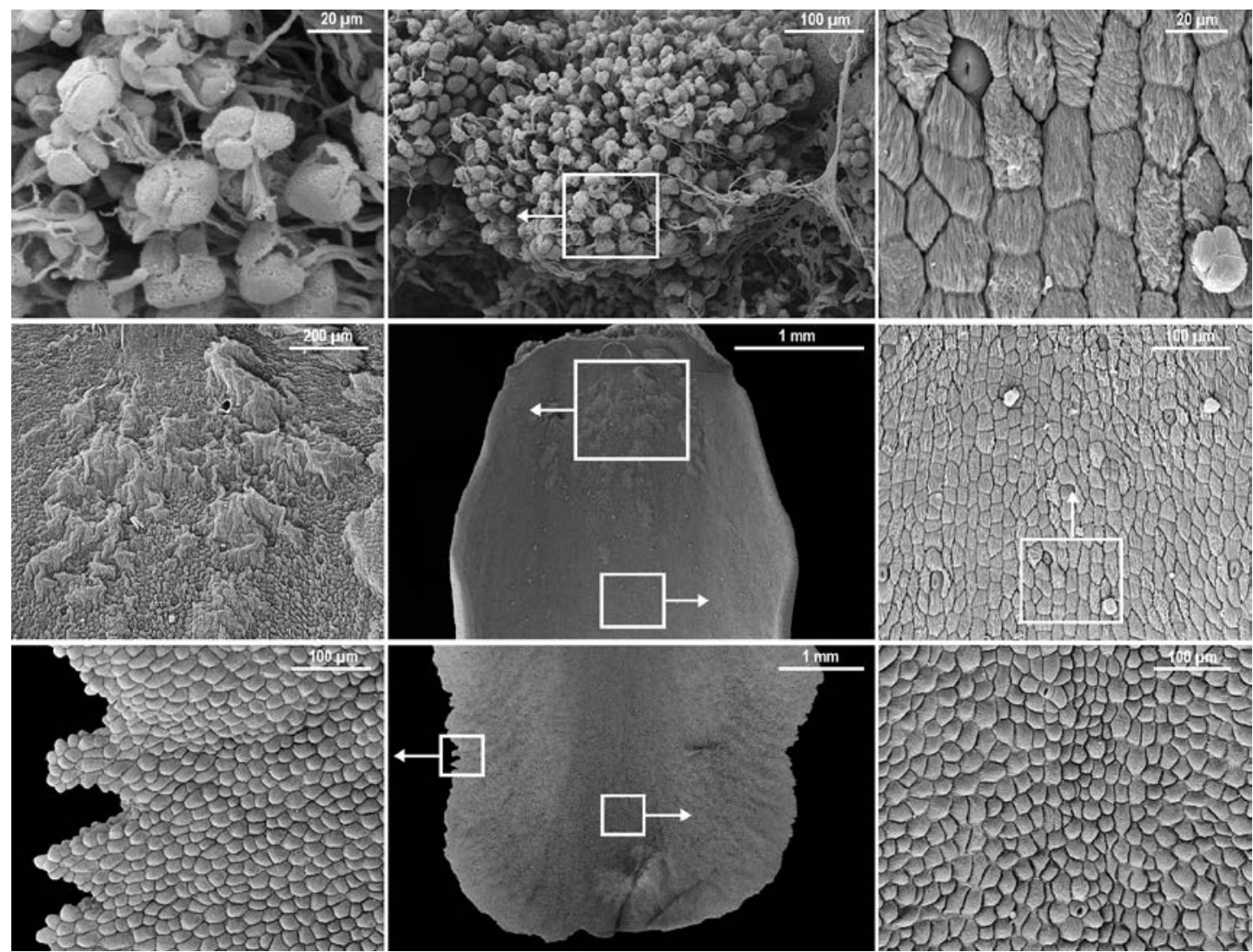

Fig. 2. Scaphyglottis cobanensis Archila, Szlach. \& S. Nowak, sp. nov. Micromorphological details of pollinia and labellum.

rose or dull brownish, lip dull whitish lilac with darker veins; ovary pedicellate, white; dorsal sepal up to $9 \mathrm{~mm}$ long and $2.8-3.0 \mathrm{~mm}$ wide, oblong, acute-acuminate at the apex, bent forward over the gynostemium; lateral sepals up to $10 \mathrm{~mm}$ long and 2.9-3.0 mm wide, obliquely oblong-triangular, acuminate, basally somewhat concave; petals up to $8.5 \mathrm{~mm}$ long and 2.0-2.1 mm wide, oblong, falcate, acute at apex; labellum up to $6.3 \mathrm{~mm}$ long and 3.0-3.1 mm wide, subpandurate in general outline, base truncate, median margins crenulate-denticulate, apical part uncinate. Gynostemium $6.7 \mathrm{~mm}$ long and $1.2 \mathrm{~mm}$ wide; column foot $1.8 \mathrm{~mm}$ long.

ETYMOLOGY. In reference to the type locality, the area surrounding the city of Cobán.

Phenology. The flowering specimens of Scaphyglottis cobanensis were observed in September and October.
DisTRIBUTION AND ECOLOGY. The new species is known so far from only one locality near San Pedrito in Guatemala. It was collected as an epiphyte growing on tree trunks and branches. Its population was found in mountain forest at $1450 \mathrm{~m}$ a.s.l.

Notes. Scaphyglottis cobanensis along with S. bifida (Fig. 3) and S. lindeniana (Fig. 4) form a group of species previously included in the genus Hexadesmia Brongn., which are easily distinguishable from other Scaphyglottis species by their peculiar habit: stalked, usually rather massive, laterally compressed pseudobulbs gathered in fascicles, with usually two large leaves at the apex, and flowers arranged along an elongate inflorescence.

The new entity resembles both $S$. lindeniana and $S$. bifida. In contrast to the former, $S$. cobanensis has rose to dull brownish flowers, the lip 

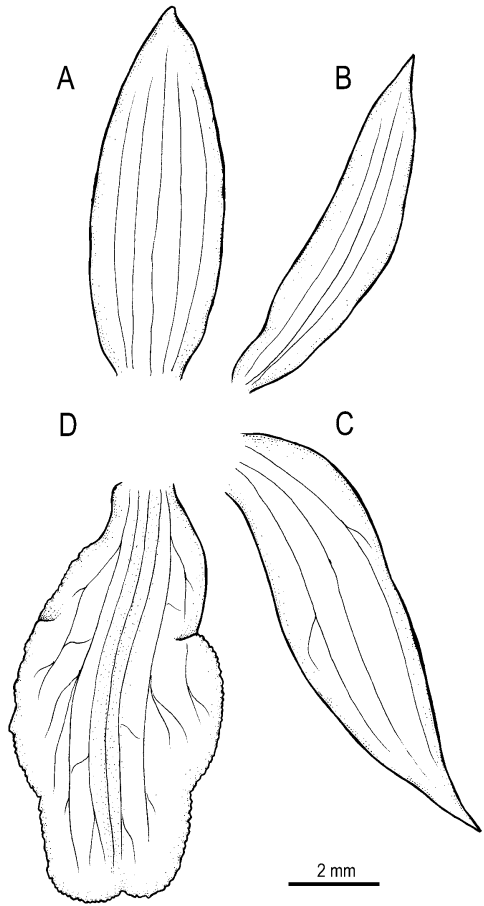

Fig. 3. Scaphyglottis bifida (Rchb. f.) C. Schweinf. A - dorsal sepal, B - petal, C - lateral sepal, D - labellum (drawn by S. Nowak from Saunders s.n., W).

is truncate at the base, the lip margins are irregularly dentate, and the leaves are large, ligulate and acute. The flowers of $S$. lindeniana are yellowish to yellow-greenish, the lip is attenuate towards the base, the margins are almost entire and the leaves are shortly bilobate at the apex. The pseudobulbs of $S$. bifida gradually narrow towards the stalked base, the brownish yellow or brownish green flowers are gathered in fascicles of fewflowered inflorescences, and the lip is rounded at the base, obscurely trilobate near the middle, with the middle lobe being split into two lobules. Hence the lip appears to be quadrilobate. Additionally, the flowering season of the new species is reported here as occurring in September and October, whereas the other species were noted to produce flowers in January and February.

ACKNOWLEDGEMENTS. We thank Dorota Łuszczak and Magdalena Narajczyk (Laboratory of Electron Micros-
A

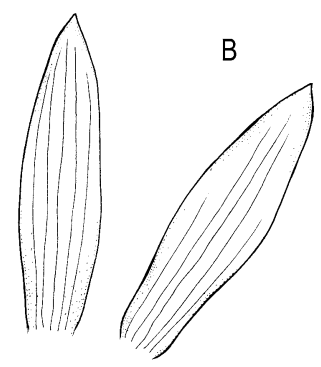

D

C

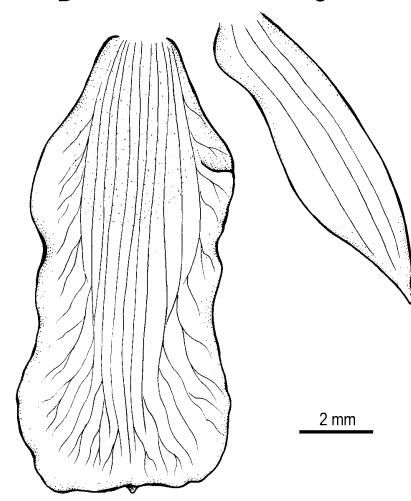

Fig. 4. Scaphyglottis lindeniana (A. Rich \& Galeotti) L. O. Williams; A - dorsal sepal, B - petal, C - lateral sepal, D - labellum (drawn by S. Nowak from Powell 229, MO).

copy, University of Gdańsk) for help in preparing the SEM micrographs, and the anonymous reviewer for critically reading the manuscript.

\section{REFERENCES}

ArChila F. 2012. Nuevas especies Guatemaltecas honrando a grandes botánicos. Revista Guatemal. 15(1): 97-114.

Archila F. \& Chiron G. 2013. Mise à Jour de la liste de Scaphyglottis (Orchidaceae, Laeliinae) au Guatemala, avec une nouvelle espèce. Richardiana 13: 177-183.

Dressler R. L. 1994. Proposal to conserve Scaphyglottis against Hexisea (Orchidaceae). Taxon 43: 665-666.

DressLer R. L. 2002. New species and combinations in Costa Rican Orchids II. Lankesteriana 3: 25-29.

DressLer R. L. 2004. Der Scaphyglottis pulchella KomplexThe Scaphyglottis pulchella complex. J. Orchideenfreund 11: 305-315.

Dressler R. L., Whitten M. \& Williams N. H. 2004. Phylogenetic relationships of Scaphyglottis and related genera 
(Laeliinae: Orchidaceae) based on nrDNA ITS sequence data. Brittonia 56: 58-66.

Dressler R. L. 2005. Scaphyglottis. In: A. M. Pridgeon, P. J. Cribb, M. W. Chase \& F. N. Rasmussen (eds), Genera Orchidacearum.4: Epidendroideae (Part 1), pp. 310-313. Oxford University Press, Oxford.

KolanowsKa M. 2013. A new species of Scaphyglottis (Orchidaceae) from the Darién Gap, Colombia. J. Torrey Bot. Soc. 140(2): 225-229.

SzlachetKo D. L. \& KolanowsKa M. 2013a. Notes on the Scaphyglottis fusiformis complex (Orchidaceae, Epiden- droideae) in Colombia with the description of two new species. Ann. Bot. Fenn. 50(5): 300-304.

Szlachetko D. L. \& KolanowsKa M. 2013b. A new species of Scaphyglottis (Orchidaceae, Epidendroideae) from Colombia. Pl. Syst. Evol. 300(5): 1031-1034.

SzlachetKo D. L. \& KolanowsKa M. 2014. Two new species of Scaphyglottis (Orchidaceae, Epidendroideae) from Colombia. Polish Bot. J. 59(1): 1-5. 